\title{
Local differences in phytoplankton-bacterioplankton coupling in the coastal upwelling off Galicia (NW Spain)
}

\author{
E. Teira ${ }^{1, *}$, V. Hernando-Morales ${ }^{1}$, A. Fernández ${ }^{1,4}$, S. Martínez-García ${ }^{1,5}$, \\ X. A. Álvarez-Salgado², A. Bode ${ }^{3}$, M. M. Varela ${ }^{3}$ \\ ${ }^{1}$ Departamento de Ecoloxía e Bioloxía Animal, Universidade de Vigo, 36200 Vigo, Spain \\ ${ }^{2}$ CSIC, Instituto de Investigacións Mariñas, Eduardo Cabello 6, 36208 Vigo, Spain \\ ${ }^{3}$ IEO, Instituto Español de Oceanografía, Centro Oceanográfico de A Coruña, Apdo. 130, 15080 A Coruña, Spain \\ ${ }^{4}$ Present address: School of Biology, Georgia Institute of Technology, Atlanta, Georgia 30332, USA \\ ${ }^{5}$ Present address: Centre for Ecology and Evolution in Microbial Model Systems (EEMiS), Linnaeus University, \\ 39182 Kalmar, Sweden
}

\begin{abstract}
We simultaneously studied microbial-mediated carbon fluxes at 2 contrasting sites within the coastal upwelling system off Galicia, near A Coruña and Vigo, Spain, over an annual cycle in order to compare the fraction of primary production released as dissolved organic carbon (DOC) and the degree of coupling between bacteria and phytoplankton. A significant fraction of primary production was released as DOC at both sites, averaging $\sim 30 \%$. DOC release accounted for, on average, $30 \%$ of the total bacterial carbon demand, which is indicative of a moderate trophic dependence of bacteria on phytoplankton in these coastal ecosystems. Nevertheless, differences in hydrographic conditions associated with stronger upwelling pulses off Vigo, and deeper upper mixed layers during the downwelling period off A Coruña, led to significant differences in phytoplankton dynamics and the subsequent direct coupling with heterotrophic bacteria. Strong direct coupling between phytoplankton extracellular release and bacterial production (BP) was found off Vigo, which could be related to the quality of the DOC produced by actively growing phytoplankton. By contrast, DOC release and BP rates were decoupled off A Coruña, likely due to unaccounted DOC associated with indirect trophic processes or to the low availability of freshly produced exudates associated with overflow or photoinhibition mechanisms.
\end{abstract}

KEY WORDS: Planktonic carbon dynamics - Coupling · Heterotrophic bacteria · Phytoplankton · Upwelling · DOC Production

\section{INTRODUCTION}

Microplanktonic organisms are key components of the biological carbon cycle in marine ecosystems. On a global scale, bacterial production accounts for 10 to $20 \%$ of contemporaneous marine primary production (Ducklow 2000). Over the last 4 decades, compelling evidence indicates that a relevant fraction (averaging 5 to $>40 \%$ ) of primary production (PP) is released as dissolved organic carbon (DOC) in most pelagic ecosystems (e.g. Thomas 1971, Teira et al. 2001a,b, 2003a, Marañón et al. 2004, López-Sandoval et al. 2011). Thus, current measurements may severely underestimate PP if concurrent measurements of DOC release are not conducted. A general inverse relationship has been observed between the percentage of extracellular release (PER) and the magnitude of primary production over wide geographical and productivity ranges (e.g. Berman \& Holm-Hansen 1974, Teira et al. 2001a, Morán et al. 2002). 
Some evidence suggests that DOC release is essentially a physiological process that can be enhanced under suboptimal light levels or under nutrient limitation conditions (Zlotnik \& Dubinsky 1989, Morán \& Estrada 2001, Marañón et al. 2004, 2005, López-Sandoval et al. 2011). On the other hand, some other studies suggest that part of the recently-fixed photosynthetic carbon might be indirectly released in dissolved form as a consequence of trophic processes, such as grazing or cell lysis, ending in cell breakage (Nagata 2000, Teira et al. 2001a,b). The dominant process implicated in DOC production may affect the quality and quantity of the released material and influence the bacterioplankton ability to use this DOC, and the degree of coupling between bacteria and phytoplankton. A recent review by Fouilland \& Mostajir (2010) clearly questions the immediate and direct dependency of bacteria on phytoplankton exudates for carbon acquisition in aquatic systems, based on the relatively small fraction of bacterial carbon demand (BCD) met by concurrent dissolved primary production. According to Fouilland et al. (2014) such a lack of direct coupling would occur under strong grazing pressure conditions, as bacteria would primarily consume indirectly released DOC.

The upwelling system off NW Spain is characterized by the episodic enrichment of inorganic nutrients into the coastal zone during spring and summer, with amplified effects due to the presence of the large coastal embayments present in that area, coined as 'rías' (e.g. Álvarez Salgado et al. 2011). Different effects of upwelling have been observed between the Rías Baixas, located to the south of Cape Fisterra, and the rías located to the north of Cape Fisterra and in the southern Bay of Biscay. In the former, the large size $\left(>2.5 \mathrm{~km}^{3}\right)$, V-shape and NE-SW orientation of the rías favours the net influx of upwelled water in response to the dominant northerly winds. The relatively warm $\left(>13^{\circ} \mathrm{C}\right)$ Eastern North Atlantic Central Water (ENACW) of subtropical origin upwells preferentially in this area, and the upwelling dynamics cause an export of the organic matter produced inside the rías to adjacent shelf areas. This leads to a very efficient utilisation of the upwelled nutrients. In the latter (to the North of Cape Fisterra), colder $\left(<13^{\circ} \mathrm{C}\right)$ and nutrient-richer ENACW of subpolar origin also usually upwells, but the N-S orientation of these rías favour upwelling under less intense and frequent easterly winds. This, together with the much smaller size of these embayments and narrowness of the shelf, does not allow efficient utilization of the upwelled nutrients (Álvarez-Salgado et al. 2011). As a consequence, higher levels of primary produc- tion have been reported for shelf waters off the Rías Baixas than those off the other rias during the productive period (e.g. Bode et al. 1994). Differences in phytoplankton community structure have been also reported between both areas along the seasonal cycle; with a lower contribution of nano- and picophytoplankton in the Rías Baixas than in the northern rias (Bode et al. 1994, Butrón et al. 2009). Differences in phytoplankton dynamics may drive changes in the carbon fluxes through the microbial communities along the seasonal cycle. Despite the seasonal variation in carbon flow through the microplanktonic communities that has been previously studied in shelf waters north of Cape Fisterra (Teira et al. 2003a), a similar study has not been conducted so far in shelf waters off the Rías Baixas.

Within this context, the objective of our work was to simultaneously study seasonal patterns in microbialmediated carbon fluxes in shelf waters off a northern ría (in front of A Coruña) and off the Rías Baixas (in front of Ría de Vigo) during an annual cycle in order to specifically compare (1) the fraction of primary production released as DOC and (2) the degree of coupling between bacteria and phytoplankton in these contrasting subtropical- and subpolar-regime environments. Differences in phytoplankton DOC release patterns are expected associated to differences in nutrient supply at both sampling sites, which may affect the direct $\mathrm{C}$-coupling between bacteria and phytoplankton.

\section{MATERIALS AND METHODS}

Sampling. Seawater samples were collected at 2 shelf stations off A Coruña (E2) and Vigo (E3) (Galicia, northwest Spain) at approximately monthly intervals from September 2009 to December 2010 (Fig. 1). In October and December 2009 and in December 2010, E3 could not be sampled because of stormy weather. At each sampling date, vertical profiles of temperature, salinity, chlorophyll-fluorescence and photosynthetically available radiation (PAR) were obtained with a SBE-25 CTD equipped with a Seapoint in situ fluorometer and a Licor spherical PAR sensor. Water from 7 fixed levels was sampled with 51 Niskin bottles that were attached to a CTD rosette sampler (A Coruña) or to the hydrographic wire (Vigo). The maximum sampling depths at E2 and E3 were 77 and $97 \mathrm{~m}$, respectively.

Aliquots for inorganic nutrients determination (ammonium, nitrite, nitrate, phosphate and silicate) were collected at all sampled depths in polyethylene 


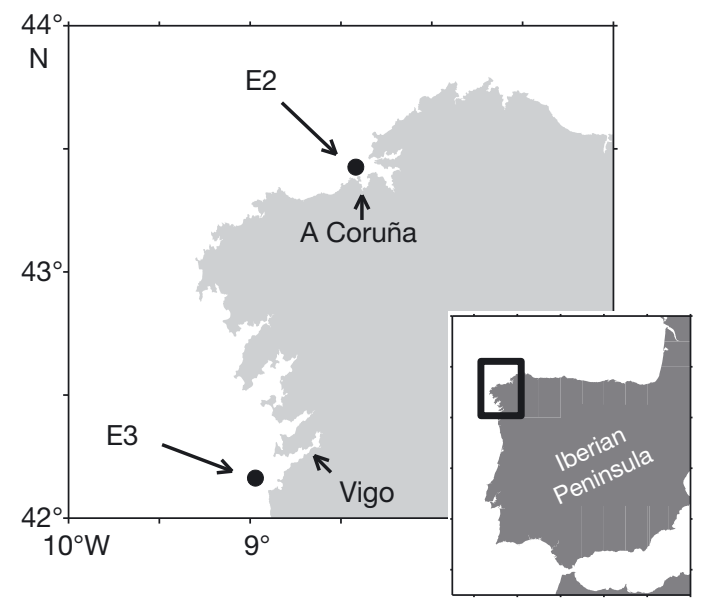

Fig. 1. Location of the sampling stations E2 and E3 off the coast of NW Spain, near the towns of A Coruña and Vigo, respectively

bottles and frozen at $-20^{\circ} \mathrm{C}$ until analysis by standard colorimetric methods with a Bran-Luebbe segmented flow analyser. Chlorophyll a (chl a) concentration was determined at all depths from acetonic extracts of plankton retained by GF/F filters and measured by the fluorimetric method (Parsons et al. 1984).

DOC concentration, particulate organic carbon and nitrogen (POC and PON) concentrations, dissolved organic matter fluorescence, particulate and dissolved primary production, bacterial biomass, bacterial production, and microbial plankton community and bacterial respiration were determined at 2 depths, corresponding approximately to the optical depths of 100 and $1 \%$ of surface PAR $\left(E_{0}\right)$ (Table 1 ). The mean depth at $1 \% E_{0}$ was $35 \mathrm{~m}$ in E2 and $40 \mathrm{~m}$ in E3. The closest to the $1 \% E_{0}$ available sampling depth in E3 was always $50 \mathrm{~m}$, where the PAR averaged $0.5 \%$ of $\mathrm{E}_{0}$, whereas at $30 \mathrm{~m}$ depth PAR averaged $5 \%$ of $E_{0}$. For simplicity we will refer to 100 and $1 \% E_{0}$ depth for both sites.

Dissolved organic matter. Water for the analysis of DOC was filtered through $0.2 \mu \mathrm{m}$ filters (Pall, Supor membrane Disc Filter) in an all-glass filtration system under positive pressure of $\mathrm{N}_{2}$, collected into pre-combusted $\left(450^{\circ} \mathrm{C}, 12 \mathrm{~h}\right) 10 \mathrm{ml}$ glass ampoules, and acidified with $\mathrm{H}_{3} \mathrm{PO}_{4}$ to $\mathrm{pH}<2$ before heat sealing. Samples were measured in a Shimadzu TOC-V analyser (Pt-catalyst). Fluorescence measurements were performed at a constant room temperature of $25^{\circ} \mathrm{C}$ in a $1 \mathrm{~cm}$ quartz fluorescence cell in a Perkin Elmer LS 55 luminescence spectrometer. Fluorescence intensity was measured at 4 fixed excitation/ emission wavelengths of 250/435 nm (FDOM-A)

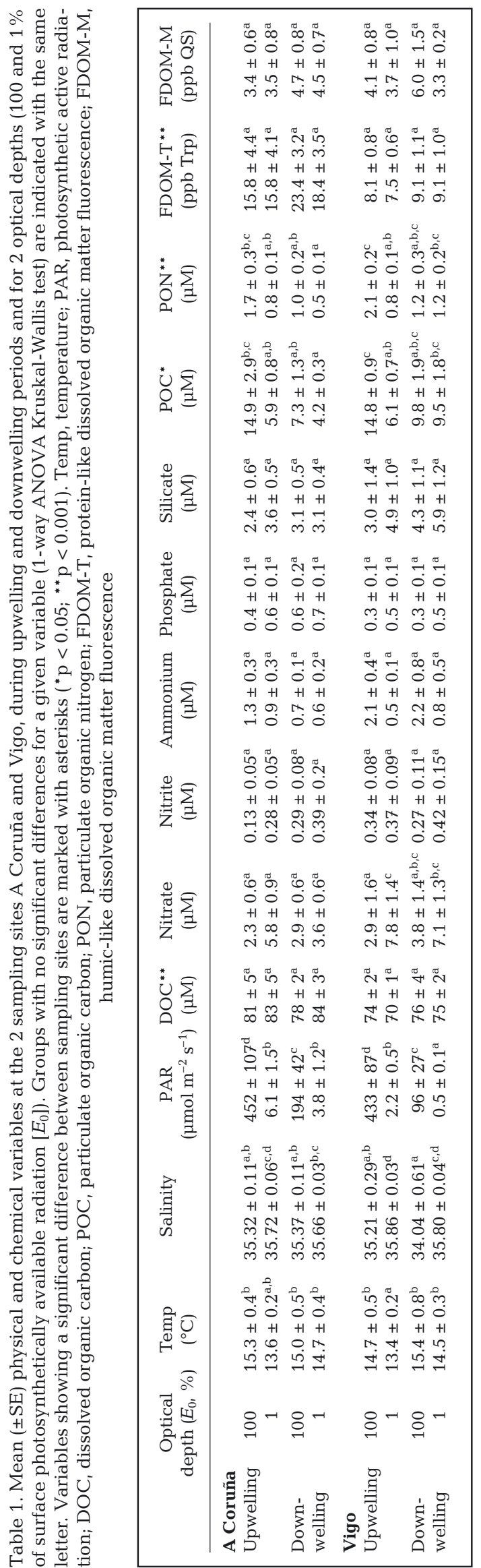


and 340/440 nm (FDOM-C), characteristic of terrestrial humic-like substances; 320/410 nm (FDOM-M), characteristic of marine humic-like substances; and of 280/350 nm (FDOM-T), characteristic of proteinlike materials (Coble 1996). Following Nieto-Cid et al. (2006), the spectrofluorometer was calibrated daily at each of the 4 fixed excitation/emission wavelengths with a mixed standard of quinine sulphate and tryptophan in $0.1 \mathrm{~N}$ sulphuric acid. FDOM-T was expressed in $\mu g \mathrm{l}^{-1}$ equivalents of tryptophan, hereafter ppb Trp, and FDOM-A, -C and $-\mathrm{M}$ in ppb equivalents of quinine sulphate (QS) (ppb QS). Equivalent concentrations were determined by subtracting the average peak height from the MQ blank height, and dividing by the slope of the standard curve. Given the high correlation between FDOM-A, -C and -M ( $\left.\mathrm{R}^{2}>0.98\right)$, only FDOM$\mathrm{M}$ and FDOM-T are presented in this study.

POC and PON. POC and PON concentrations were determined in 0.5-1.0 l of seawater filtered through Whatman GF/F filters, which were stored frozen $\left(-20^{\circ} \mathrm{C}\right)$ until analysis in a Carlo Erba CHNSO 1108 analyser.

Particulate and dissolved primary production. For each sampling depth, 3 light and 2 dark acid-washed Pyrex glass bottles (36 $\mathrm{ml}$ in volume) were filled with seawater sample, inoculated with $74370 \mathrm{KBq}$ $(2-10 \mu \mathrm{Ci})$ of $\mathrm{NaH}^{14} \mathrm{CO}_{3}$ and then incubated ashore for $2-3 \mathrm{~h}$ in an incubator which simulated the irradiance experienced by the cells at the original sampling depths. Experimental incubations always started around 14:00 h local time. Bottles were maintained at surface seawater temperature during incubation. Two $5 \mathrm{ml}$ subsamples were drawn from each bottle and filtered through $0.2 \mu \mathrm{m}$ polycarbonate membrane filters using low vacuum pressure $(<7 \mathrm{kPa})$. Labelled dissolved inorganic carbon was removed by acidifying the filters and filtrates with $100 \mathrm{\mu l}$ of $50 \% \mathrm{HCl}$ for $12 \mathrm{~h}$. The filtrates were maintained in open scintillation vials (20 $\mathrm{ml}$ in volume) placed on an orbital shaker. A scintillation cocktail was then added to filters $(4.5 \mathrm{ml})$ and filtrates $(10 \mathrm{ml})$. The radioactivity on each sample was determined with a $\beta$-scintillation counter that used an internal standard for quenching correction. Black bottle DPMs (disintegrations per minute) were subtracted from the light bottle DPMs in order to calculate the production rates of dissolved organic carbon (DOCp) and particulate organic carbon (POCp). The light to dark bottle DPM ratio was on average 2.3 for the filtrates. We used a constant value of $24700 \mathrm{mg} \mathrm{m}^{-3}$ for the concentration of dissolved inorganic carbon and a value of 1.05 for the isotopic discrimination factor. For all pooled rate determinations of POCp and DOCp ( $=58)$, the percentages of relative standard error (SE/mean) were 12 and $17 \%$, respectively. Total organic carbon production (TOCp) was estimated as the sum of POCp and DOCp rates. The percentage of PER was calculated by dividing DOCp by TOCp rates. Daily rates were obtained from hourly rates using the corresponding daylight length which ranged from 9 to $15.4 \mathrm{~h}$ during the sampling period.

Bacterial biomass (BB). The abundance of heterotrophic bacteria was determined with a Becton Dickinson FACSCalibur flow cytometer equipped with a laser emitting at $488 \mathrm{~nm}$ (Calvo-Díaz \& Morán 2006). Samples $(1.8 \mathrm{ml})$ were preserved with $1 \%$ paraformaldehyde $+0.05 \%$ glutaraldehyde, and frozen at $-80^{\circ} \mathrm{C}$ until analysis. Prior to analysis, heterotrophic bacteria were stained with $2.5 \mathrm{mM}$ SybrGreen DNA fluorochrome.

Bacteria were identified on the basis of their fluorescence and light side scatter (SSC) signatures. The empirical calibrations between SSC and mean cell diameter described in Calvo-Díaz \& Morán (2006) were used to estimate biovolume (BV) of heterotrophic bacteria. BV was finally converted into biomass by using the allometric relationship of Norland (1993): $\mathrm{fg} \mathrm{C} \mathrm{cell}{ }^{-1}=120 \times \mathrm{BV}^{0.72}$ for heterotrophic bacteria.

Bacterial heterotrophic production (BP). The $\left[{ }^{3} \mathrm{H}\right]-$ leucine incorporation method (Kirchman et al. 1985), modified as described by Smith \& Azam (1992), was used to determine leucine (Leu) incorporation rates (LIR). Leucine was added at $40 \mathrm{nM}$ final concentration. Samples were incubated for $2 \mathrm{~h}$ in the same incubation chamber as the POC and DOC production bottles. Incubations were stopped by adding cold trichloroacetic acid (final concentration 5\%). For comparative purposes, we used a theoretical leucine to carbon conversion of $3.1 \mathrm{~kg} \mathrm{C} \mathrm{mol} \mathrm{Leu}{ }^{-1}$. Bacterial growth efficiency (BGE) was calculated as: BP/(BP + bacterial respiration). Bacterial growth rate (BGR) was calculated as: $\ln (1+\mathrm{BP} / \mathrm{BB})$.

Microbial plankton community respiration (CR) and bacterial respiration (BR). INT (2-para (iodophenyl)-3(nitrophenyl)-5(phenyl) tetrazolium chloride) reduction rate was used as estimator of microbial CR using the in vivo INT reduction method (Martínez-García et al. 2009). Four $100 \mathrm{ml}$ dark bottles were filled from each sampling depth. Formaldehyde-killed controls ( $2 \%$ v/v final concentration) were performed in order to account for any abiotic reduction of INT (Martínez-García et al. 2009); however, formaldehyde-sensitive abiotic reduction (i.e. 
some cell-free enzymes) was not accounted for in the killed controls. Samples were spiked with INT (final concentration $0.2 \mathrm{mM}$ ) and incubated in the same incubator used for primary production for 1-1.5 h. After incubation, samples were sequentially filtered through $0.8 \mu \mathrm{m}$ and $0.2 \mu \mathrm{m}$ pore size polycarbonate filters. The reduced INT (INT formazan) was extracted from the filters with propanol as described in Martínez-García et al. (2009). Respiration of free-living heterotrophic bacteria (i.e. BR) was operationally defined as ETS activity $<0.8 \mu \mathrm{m}$ (Robinson 2008). In order to transform INT reduction rates into carbon respiration, an R/ETS ratio of 12.9 (empirically derived for a non-axenic culture of Isochrysis galbana) (Martínez-García et al. 2009) and a respiratory quotient (RQ) of 0.89 (Williams \& del Giorgio 2005) were used. BCD was calculated as the sum of BP and BR. The reported variability in average RQ (0.7-1.2; Williams \& del Giorgio 2005) or R/ETS ratio (12.5-19.1; Martínez-García et al. 2009) support that the use of constant values should not introduce large uncertainty in the estimation of respiration rates.

Upwelling intensity and upper mixed layer (UML) depth. The upwelling intensity was estimated by calculating the Ekman transport from surface winds as an upwelling index (Iw). Daily Iw values were computed by the Instituto Español de Oceanografía (www.indicedeafloramiento.ieo.es/) in 2 cells of $1^{\circ} \times$ $1^{\circ}$ centered at $43.5^{\circ} \mathrm{N}, 9^{\circ} \mathrm{W}$ for $\mathrm{E} 2$ and $42^{\circ} \mathrm{N}, 10^{\circ} \mathrm{W}$ for E3, using data from atmospheric pressure at sea level, derived from the WXMAP model (GonzálezNuevo et al. 2014).

UML depth was determined as the depth where temperature is $0.25^{\circ} \mathrm{C}$ lower than in the surface. The nitracline is defined as the depth where nitrate concentration is equal or higher than $1 \mu \mathrm{M}$.

Statistical analyses. Non-parametric tests were applied because of the non-normal distribution of most of the variables considered. A Kruskal-Wallis (K-W) test was used for comparison between samples from A Coruña and Vigo, with the null hypothesis that the 2 groups have the same distribution. The 1 -way ANOVA K-W test was used in order to test for differences between 3 or more groups for a given variable. The ANOVA $\mathrm{K}-\mathrm{W}$ test is a non-parametric equivalent to a 1 -way analysis of variance by ranks. It tests the null hypothesis that 3 or more groups all come from the same distribution. It uses the ranks of data and is therefore resistant to outliers. The MannWhitney significance test was applied a posteriori to analyse the differences between every pair of groups.

\section{RESULTS}

\section{Hydrographic conditions}

The distribution of the monthly offshore Iw during the sampling period (Fig. 2) was characterized by upwelling-favourable conditions (as inferred from positive values) in September 2009 and from MarchApril to August-September 2010 at both sampling locations. Downwelling conditions (as inferred from negative values) predominated from October 2009 to February-March 2010 and from September-October to December 2010. Upwelling intensity was higher off Vigo than in A Coruña during summer, whereas downwelling intensity was higher off A Coruña than in Vigo in October-November 2009 and 2010.

The thermohaline variability throughout the sampling period was essentially driven by the typical seasonal thermal cycle and by upwelling pulses during spring and summer (Fig. 3A,B, Table 1). Samples were classified into upwelling (Up) and downwelling $(\mathrm{Dw})$ periods based on the Iw and the temperature profiles (Figs. 2 \& 3A,B). The upwelling period included samples from September 2009 and from March to August 2010. The downwelling period included samples from October 2009 to February 2010, and from September to December 2010 (Table 1).

Thermal inversions were observed in Vigo in November 2009 and from January to March 2010, as a consequence of freshwater runoff, leading to the development of a narrow upper mixed layer of haline stratification (Fig. 3B). The relatively low mean salinity (34.04) in surface waters off Vigo during downwelling strongly supports the influence of freshwater

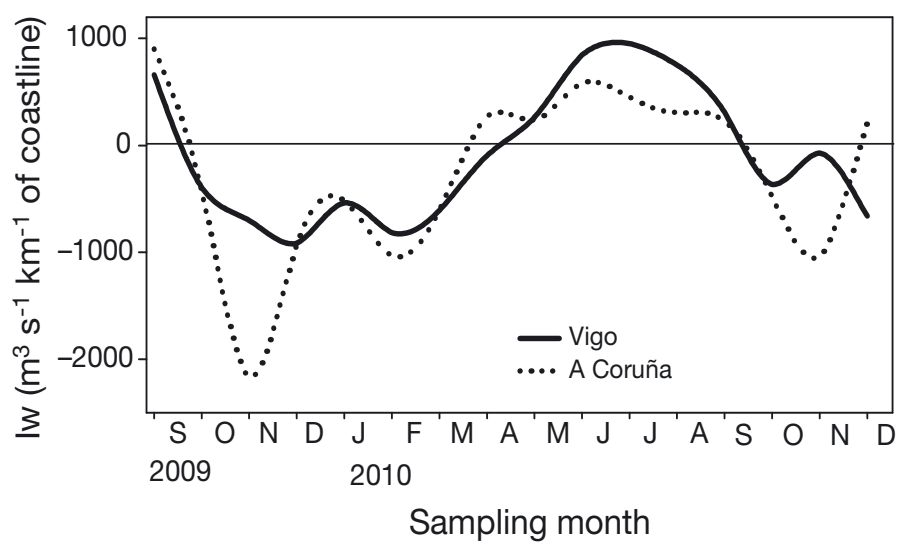

Fig. 2. Distribution of monthly offshore upwelling index (Iw) at E2 (A Coruña) and E3 (Vigo) during the sampling period 


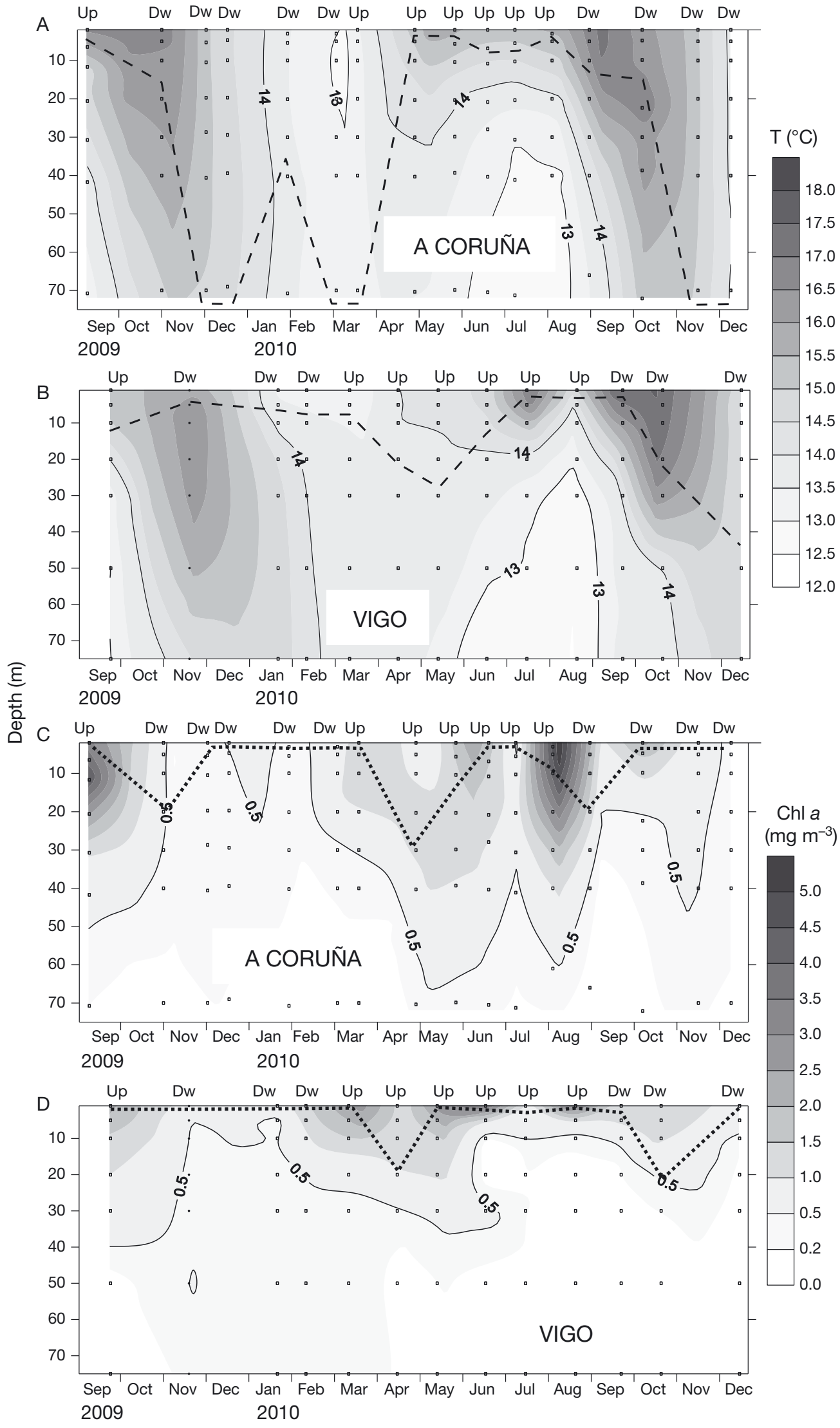

Fig. 3. Vertical distribution of temperature off (A) A Coruña and (B) Vigo, and chlorophyll a concentration off (C) A Coruña and (D) Vigo throughout the sampling period. Dashed lines in (A) and (B) indicate the upper mixed layer (UML) depth; dotted lines in (C) and (D) indicate the nitracline depth. 'Up', upwelling; 'Dw', downwelling 
runoff off the Rias Baixas (Table 1). Strong upwelling pulses during summer (June-August 2010) introduced deep and cold waters near the surface. The strongest upwelling pulse occurred in August 2010 off Vigo, when $<13^{\circ} \mathrm{C}$ water reached $25 \mathrm{~m}$ depth (Fig. 3B). Downwelling of shelf surface waters, promoted by the dominance of southerly winds, was observed in October-November both in 2009 and 2010. The intensity of downwelling was higher off A Coruña than off Vigo (Fig. 2), which was reflected by the deeper UML observed during autumn and winter (Fig. 3A,B).

\section{Inorganic nutrients and dissolved and particulate organic matter}

Mean inorganic nutrient concentrations (nitrate, nitrite, ammonium, phosphate and silicate) were high at both stations, and no significant differences were observed between both sampling sites (Table 1). Significant differences were observed among sample groups for nitrate concentration, which was significantly higher at $1 \% E_{0}$ than at $100 \% E_{0}$ depth during the upwelling period off Vigo (Table 1). Mean nitracline depth was deeper off A Coruña $(10 \mathrm{~m})$ than off Vigo $(2.8 \mathrm{~m})$ during the upwelling period (Fig. 3C,D). Mean DOC concentration varied from 70 to $84 \mu \mathrm{M} \mathrm{C}$ and was significantly higher off A Coruña than off Vigo ( $\mathrm{K}-\mathrm{W}$ test, $\mathrm{p}=0.005)$. However, no significant differences were found among different groups (Table 1). Although no significant differences were found for FDOM-M between both sampling sites, FDOM-T was significantly higher off A Coruña than off Vigo (K-W test, $\mathrm{p}=0.003)$. However, a posteriori comparisons among groups did not detect significant differences (Table 1). Significantly higher POC and PON concentrations were measured off Vigo than off A Coruña (K-W test, $\mathrm{p}<0.02)$. POC concentration was significantly higher at $100 \% E_{0}$ than at $1 \% E_{0}$ depth during the upwelling period off Vigo.

\section{Phytoplankton biomass and production}

Phytoplankton biomass, estimated from chl a concentration, showed the highest values between surface and $10 \mathrm{~m}$ depth off Vigo (Fig. 3D) and between surface and $20 \mathrm{~m}$ depth off A Coruña (Fig. 3C). The highest values were measured in surface waters in August 2010, both off A Coruña $\left(6.3 \mathrm{mg} \mathrm{m}^{-3}\right)$ and Vigo $\left(4.3 \mathrm{mg} \mathrm{m}^{-3}\right)$. Low chl a concentrations $(<0.8 \mathrm{mg}$ $\mathrm{m}^{-3}$ ) were measured throughout the whole water col- umn during winter months at both sites and in July 2010 off A Coruña. Extremely low values $(<0.25 \mathrm{mg}$ $\mathrm{m}^{-3}$ ) were encountered off Vigo below $20 \mathrm{~m}$ depth during the summer (Fig. 3D). Chl a concentration at $100 \% E_{0}$ depth followed roughly the same temporal variability pattern at both sites (Fig. 4A,B), alternating peaks of high and low chl a during the upwelling period. By contrast, chl a temporal variability was much higher off A Coruña than off Vigo at $1 \% E_{0}$ depth (Fig. 4A,B). Chl a concentration at the base of the euphotic zone was significantly higher in A Coruña than in Vigo during the upwelling period (1-way ANOVA K-W test, Table 2). Water-column (0 to 60-75 m) integrated chl a concentration (data not shown) ranged from 18 to $147 \mathrm{mg} \mathrm{m}^{-2}$ off A Coruña and from 18 to $58 \mathrm{mg} \mathrm{m}^{-2}$ off Vigo, although there was no statistically significant difference between the 2 sites (K-W test, $\mathrm{p}>0.05$ ).

TOCp rates followed very similar patterns than those of chl a in surface waters at both sites (Fig. 4C,D), whereas uncoupling between chl $a$ and TOCp rates was observed off A Coruña at $1 \% E_{0}$ depth (Fig. 4A,C). The highest TOCp rates ( $>400 \mathrm{mg}$ $\mathrm{C} \mathrm{m}{ }^{-3} \mathrm{~d}^{-1}$ ) were measured in surface waters off Vigo in March, June and August 2010 and in surface waters in September 2009 off A Coruña. There were no significant differences in TOCp rates between A Coruña and Vigo (Table 2). DOCp rates ranged from 1 to $47 \mathrm{mg} \mathrm{C} \mathrm{m}^{-3} \mathrm{~d}^{-1}$ in surface waters and from 0.5 to $14 \mathrm{mg} \mathrm{C} \mathrm{m}^{-3} \mathrm{~d}^{-1}$ at the base of the euphotic zone (Fig. 4E,F). There were no significant differences between the 2 sampling sites (K-W test, $\mathrm{p}>0.05$ ).

Derived PER ranged from 1 to $60 \%$ in surface waters and from 13 to $83 \%$ at the base of the euphotic zone (Fig. 4G,H), and there were no significant differences between sampling locations (K-W test, $\mathrm{p}>0.05)$. PER was significantly higher at $1 \% E_{0}$ than $100 \% E_{0}$ depth off Vigo during both the upwelling and downwelling periods (Table 2). By contrast, PER values were not significantly different at the surface and at the base of the euphotic zone during both periods off A Coruña (Fig. 4G, Table 2), although they were always higher at the $1 \% E_{0}$.

While high PER values (>40\%) were consistently measured at very low irradiances at both sites, high PER values $(>40 \%)$ were also observed at higher irradiances during the downwelling period off A Coruña. In addition, relatively high PER values $(>20 \%)$ were measured for some surface samples during the upwelling period off A Coruña (Fig. 5A,B).

There was a highly significant log-log linear relationship between TOCp and chl a concentration both off A Coruña $\left(p=0.001, r^{2}=0.48\right)$ and Vigo $(p<0.001$, 

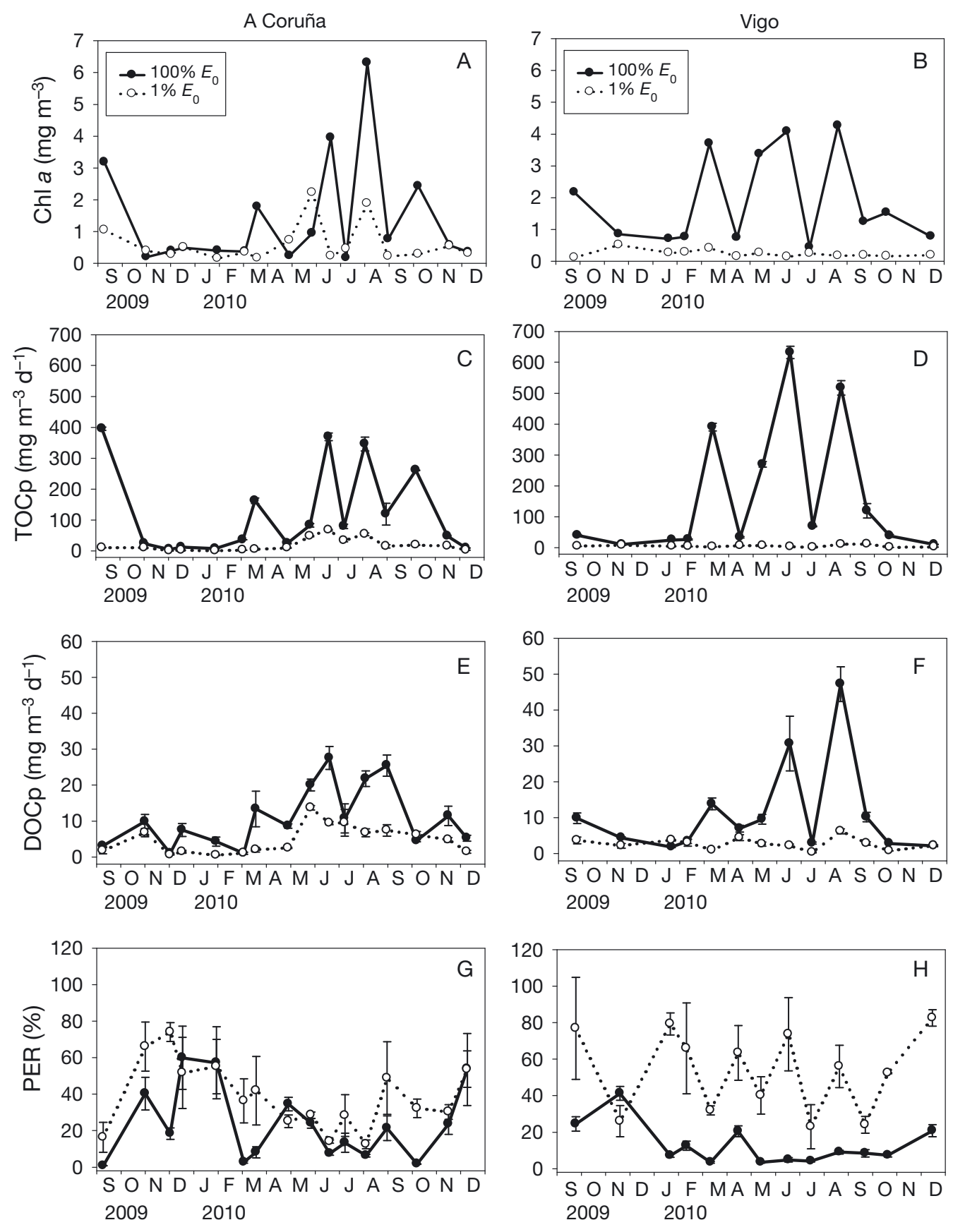

Sampling month

Fig. 4. Seasonal variation of mean $( \pm \mathrm{SE})(\mathrm{A}, \mathrm{B})$ chlorophyll a $(\mathrm{chl} a),(\mathrm{C}, \mathrm{D})$ total organic carbon production $(\mathrm{TOCp}),(\mathrm{E}, \mathrm{F})$ dissolved organic carbon production (DOCp) and $(\mathrm{G}, \mathrm{H})$ percentage of extracellular release (PER) at optical depths of 100 and $1 \%$ of surface photosynthetically available radiation $\left(100 \% E_{0}\right.$ and $1 \% E_{0}$, respectively) off $(A, C, E, G) A$ Coruña and $(B, D, F, H)$ Vigo

$\mathrm{r}^{2}=0.73$ ) (Fig. 6A,B), although chl a concentration explained only $48 \%$ of variability in TOCp off A Coruña. Similarly, a significant relationship was also found between $\log (\mathrm{chl} a)$ concentration and PER off Vigo $\left(p<0.001, r^{2}=0.60\right)$ and A Coruña $(p=0.023$, $\mathrm{r}^{2}=0.15$ ) (Fig. 6C,D), although chl a concentration explained only $15 \%$ of variability in PER off
A Coruña. Whereas high PER values ( $>42 \%$ ) occurred off Vigo when chl a concentration was $<0.26 \mathrm{mg} \mathrm{m}^{-3}$; high PER values $(>42 \%$ ) occurred off A Coruña at chl a concentrations $<0.5 \mathrm{mg} \mathrm{m}^{-3}$ (Fig. 6C,D).

A statistically significant log-log linear relationship was found between DOCp and POCp rates at both sites (Fig. 6E,F). POCp explained $53 \%$ of the variabil- 


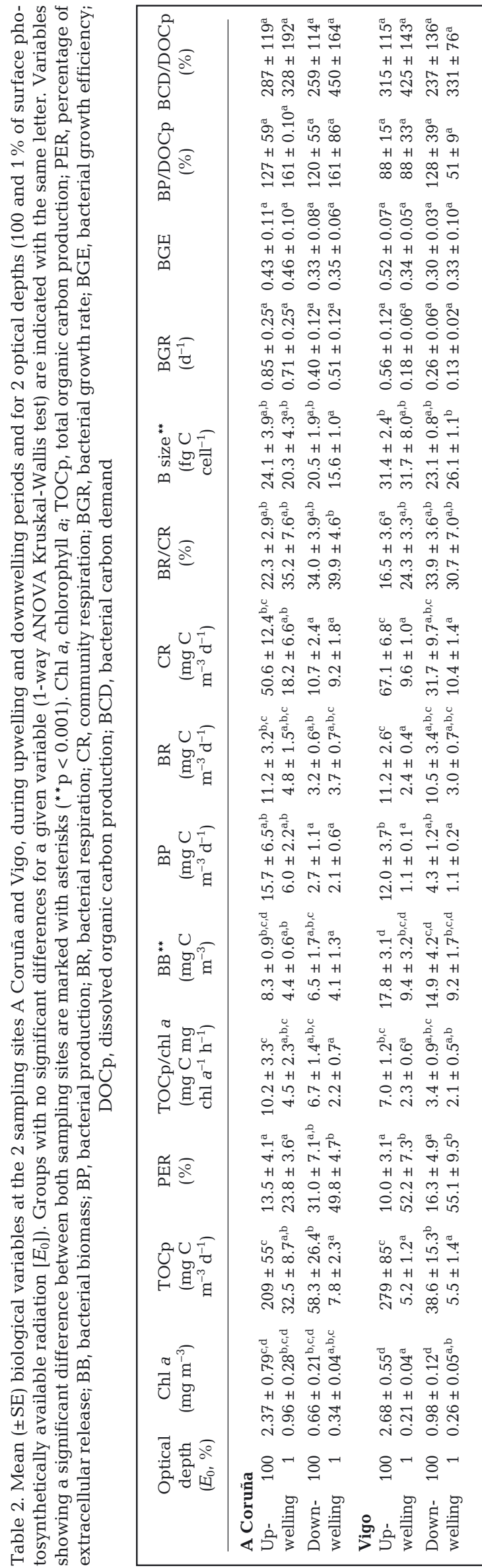

ity observed in DOCp production both off A Coruña and Vigo. The corresponding ordinary least squares (OLS), or Model I, linear regression slopes obtained from A Coruña $(b=0.42 \pm 0.07)$ and Vigo $(b=0.37 \pm$ 0.07 ) datasets were not significantly different (ANCOVA F-test, $\mathrm{p}=0.08$ ). The intercepts of the regressions were also not significantly different (ANCOVA $F$-test, $\mathrm{p}=0.10$ ). Major axis regression, or Model II, where error is inherent to both $x$ and $y$ variables, produced slopes of $0.58 \pm 0.07$ and $0.51 \pm 0.07$ for A Coruña and Vigo, respectively. Model II slopes were also not significantly different ( $t$-test, $p=0.28$ ), and both were significantly smaller than $1(t$-test, $\mathrm{p}<$ 0.05), meaning that PER decreases with productivity at both sites.

\section{Bacterial biomass and heterotrophic microbial plankton metabolism}

$\mathrm{BB}$ ranged from 2 to $37 \mathrm{mg} \mathrm{C} \mathrm{m}^{-3}$ and was only slightly higher at $100 \% E_{0}$ than at $1 \% E_{0}$ depth, showing highest values in surface waters during the downwelling period and lowest values during winter months at both sites (Fig. 7A,B). BB was significantly higher off Vigo than off A Coruña (K-W test, $\mathrm{p}<$ 0.001), particularly during the downwelling period (1-way ANOVA K-W test, Table 2). Bacterial cell size ranged from 12 to $73 \mathrm{fg} \mathrm{C}$ cell $^{-1}$ and was also significantly higher off Vigo than off A Coruña (K-W test, $\mathrm{p}<0.001$, Table 2). Bacterial production rates varied by 2 orders of magnitude, from values of $<0.2$ up to $52 \mathrm{mg} \mathrm{C} \mathrm{m}^{-3}$ (Fig. 7C,D). Highest values were measured in July 2010 off A Coruña and August 2010 off Vigo. No significant differences were found in BP between A Coruña and Vigo (K-W test, $\mathrm{p}>0.05)$. BP was significantly higher at $100 \% E_{0}$ than at $1 \% E_{0}$ depth off Vigo during the upwelling period (1-way ANOVA K-W test, Table 2). Despite significant differences in $\mathrm{BB}$ and bacterial cell size, there were no significant differences in specific BGR between A Coruña and Vigo (K-W test, $\mathrm{p}>0.05$, Table 2). $\mathrm{BB}$ was not significantly related to BP off A Coruña (Fig. 8A), whereas a weak but significant relationship was found off Vigo (Fig. 8B). BP was not significantly related to DOCp off A Coruña, whereas a significant relationship was observed off Vigo, with DOCp explaining $55 \%$ of the variability observed in BP (Fig. 8C,D). On average, DOCp contributed $88 \%$ of BP off Vigo, whereas mean BP exceeded mean DOCp off A Coruña (data not shown), although no significant differences were found between BP/DOCp ratios at both sites (Table 2). BR ranged from 0.55 to 


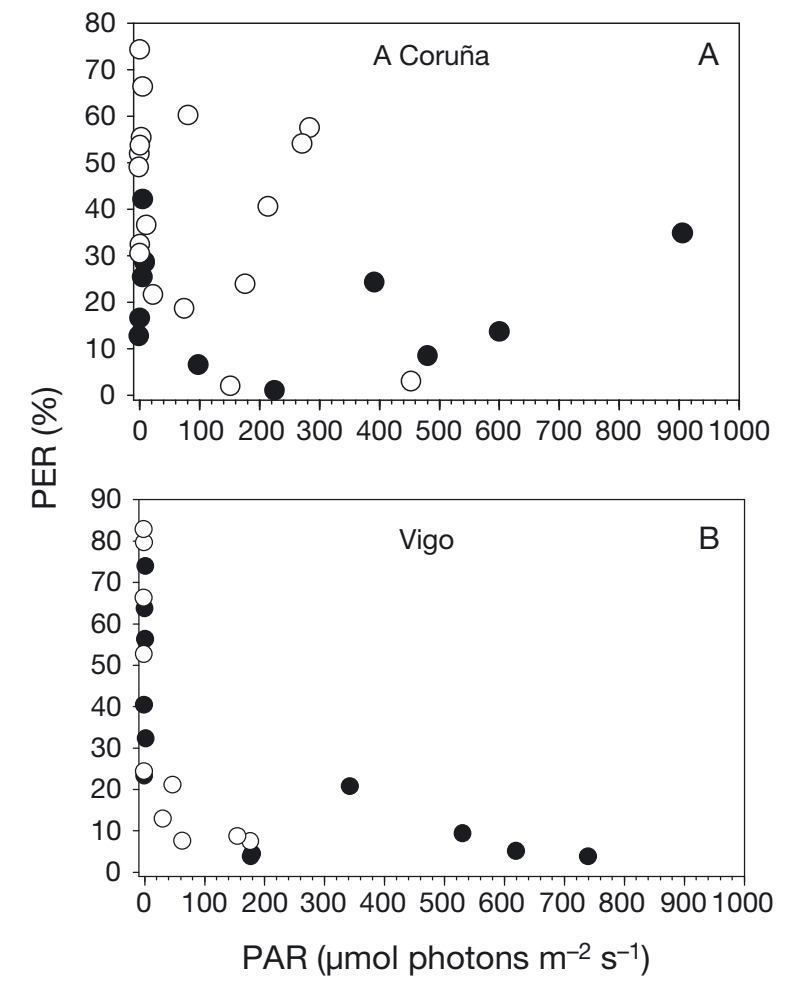

Fig. 5. Relationship between percentage of extracellular release (PER) and irradiance off (A) A Coruña and (B) Vigo. Samples from the $1 \% E_{0}$ (optical depths of $1 \%$ of surface photosynthetically available radiation [PAR]) showed PAR values $<20 \mu \mathrm{mol}$ photons $\mathrm{m}^{-2} \mathrm{~s}^{-1}$ at both sampling sites. Black and white symbols represent data from the upwelling and downwelling period, respectively

$25 \mathrm{mg} \mathrm{C} \mathrm{m}{ }^{-3}$ (Fig. 7E,F), and no significant differences were found between A Coruña and Vigo (K-W test, $\mathrm{p}>0.05$, Table 2). BR was significantly higher at $100 \% E_{0}$ than at $1 \% E_{0}$ depth off Vigo during the upwelling period (Table 2). The resulting BGE ranged from 0.05 to 0.85 , averaging 0.38 at both sites. BCD was significantly related to DOCp only off Vigo, where DOCp explained $32 \%$ of the variability observed in BCD. BCD largely exceeded DOCp rates at both sites (Fig. 8E,F), with BCD/DOCp ratios averaging 3 and 3.34 off Vigo and A Coruña, respectively (Table 2). On average, BP and BCD represented respectively, $5.5 \%$ and $13.3 \%$ of TOCp off Vigo, and $8.7 \%$ and $16.5 \%$ off A Coruña (data not shown), although the differences were not significant between sites (K-W test, $\mathrm{p}>0.05)$.

Microbial plankton CR followed a rather similar temporal pattern at both sampling sites (Fig. 7G,H). CR ranged from 4.25 to $99 \mathrm{mg} \mathrm{C} \mathrm{m}^{-3} \mathrm{~d}^{-1}$ in surface waters and from 2.0 to $58 \mathrm{mg} \mathrm{C} \mathrm{m}^{-3} \mathrm{~d}^{-1}$ at the base of the euphotic zone, with no significant differences between both sites (K-W test, $\mathrm{p}>0.05$ ). CR was sig- nificantly higher at $100 \% E_{0}$ than at $1 \% E_{0}$ during the upwelling period off Vigo (Table 2). Overall, TOCp exceeded CR (Table 2), suggesting that these 2 coastal systems are autotrophic. On average, BR represented 26 and $34 \%$ of total community respiration off Vigo and A Coruña, respectively (Table 2).

\section{DISCUSSION}

\section{Differences in planktonic carbon dynamics}

Both sampling locations were seasonally affected by upwelling events, and we did not find major differences in mean planktonic carbon budgets between the sites (as described from variables included in Table 2). However, we did find some important differences in hydrographic conditions which appear to influence phytoplankton DOC production and, in turn, affect the degree of direct C-coupling between phytoplankton and heterotrophic bacteria.

During the upwelling period, the intermittent advection of subsurface cold and nutrient-rich water modulates the position of the thermocline within the water column, which in turn affects nutrient supply rates. The higher Iw observed off Vigo than off A Coruña during the upwelling period (Fig. 2), promoted the advection of nutrient-rich cold waters closer to the surface waters off Vigo than off A Coruña, as reflected by the position of the $14^{\circ} \mathrm{C}$ isotherm (Fig. 3A,B) and the upper position of the nitracline off Vigo (mean depth $2.8 \mathrm{~m}$, Fig. 3D) compared to A Coruña (mean depth 10 m, Fig. 3C), which would imply a higher nutrient supply for phytoplankton in surface waters off Vigo than off A Coruña. The extremely low concentration of $\mathrm{chl} a$ at $30 \mathrm{~m}$ depth off Vigo during the intense upwelling pulses (Fig. 3D) suggests that we sampled recently upwelled waters in front of the Rías Baixas. On the other hand, the downwelling episodes, when phytoplankton is transported from the surface to deeper layers where irradiance levels are lower and, therefore, carbon fixation could be limited, were more intense off A Coruña than off Vigo. Such intense downwelling events caused a strong mixing of the upper water column off A Coruña during the autumn and winter months (Fig. 3A) which could cause the photoacclimation of phytoplankton to low average irradiance within such a deep upper mixed layer. Conversely, haline stratification during the downwelling period prevented intense mixing of the water column off Vigo. Lower assimilation numbers were measured off A Coruña (0.3-0.7 $\mathrm{mg} \mathrm{C}[\mathrm{mg} \mathrm{chl} \mathrm{a}]^{-1}$ 

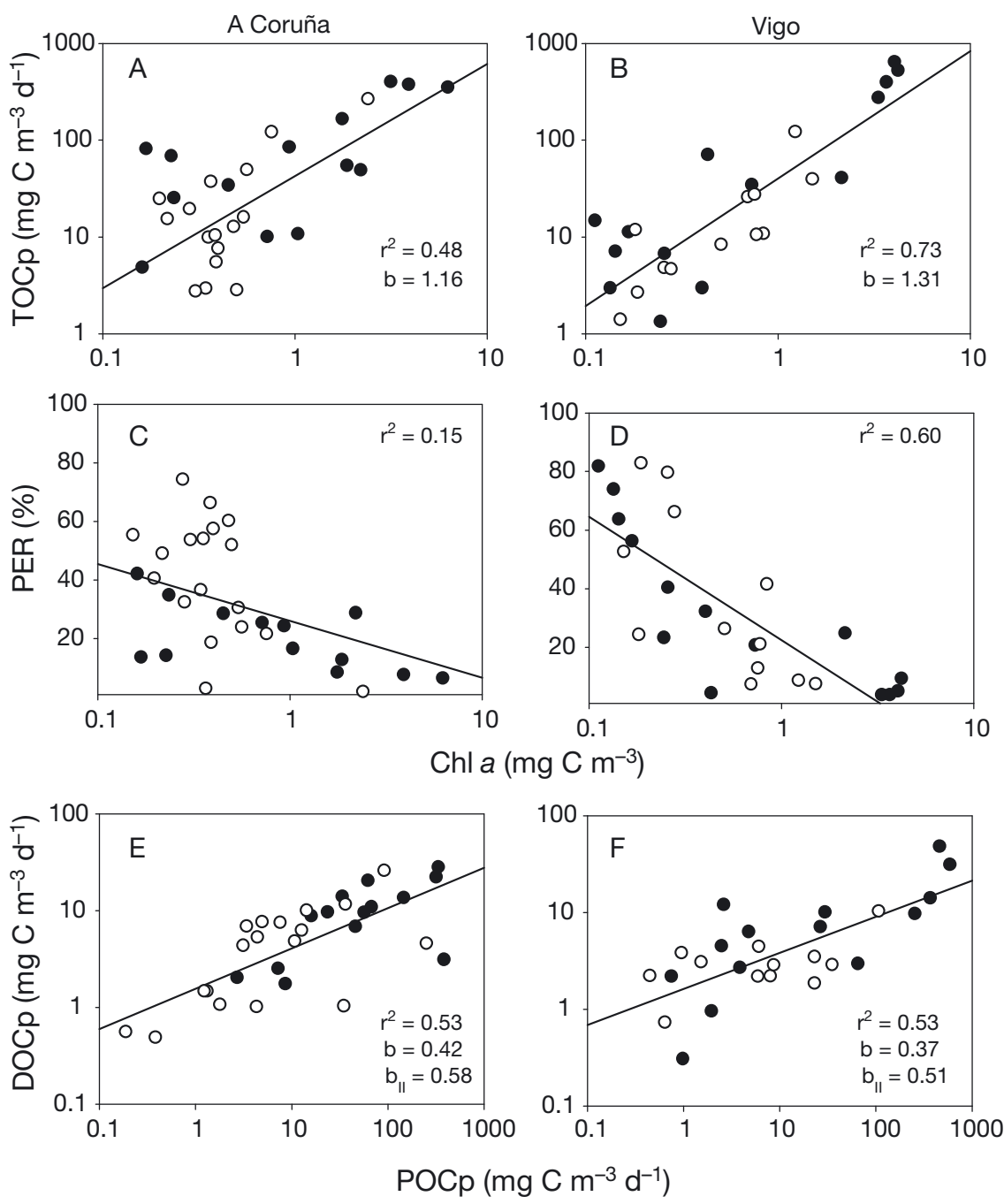

Fig. 6. Relationship between $(\mathrm{A}, \mathrm{B})$ total organic carbon production $(\mathrm{TOCp})$ and chlorophyll a ( $\mathrm{chl} a),(\mathrm{C}, \mathrm{D})$ percentage of extracellular release (PER) and chl $a$ and $(\mathrm{E}, \mathrm{F})$ dissolved organic carbon production (DOCp) and particulate organic carbon production (POCp) off $(A, C, E)$ A Coruña and $(B, D, F)$ Vigo. Black and white symbols represent data from the upwelling and downwelling period, respectively. ' $\mathrm{b}$ ' and ' $\mathrm{b}_{\mathrm{II}}$ ' represent Model I and Model II regression slopes, respectively

$\mathrm{h}^{-1}$, data not shown) than off Vigo (1.7-1.9 $\mathrm{mg} \mathrm{C}[\mathrm{mg}$ chl $a]^{-1} \mathrm{~h}^{-1}$, data not shown) at the $1 \% E_{0}$ depth from December 2009 to February 2010, which may be related to light limitation associated with deeper water column mixing.

Mean DOCp rates, PER values and the log-log relationship between POCp and DOCp were similar at both sampling sites, which may suggest that similar processes are involved in DOC release by phytoplankton in these 2 nearby coastal stations. As previously observed in the sampling sites (Teira et al. $2001 b, 2003 a)$ the slopes of the log-log linear regressions (Model II) between volumetric DOCp and
POCp were significantly less than 1 (Fig. 6E,F), which implies that PER tends to increase with decreased POCp. Considering that, in our shortterm ${ }^{14} \mathrm{C}$ experiments, we measured DOC production as the release of radiolabeled DOC that has recently been fixed by phytoplankton cells, most of the DOCp measured after our incubations will likely derive from direct physiological processes such as passive diffusion or active exudation. Hence, this does not preclude that other indirect processes such as grazing or cell lysis, producing DOC with a lower specific radioactivity, may be also relevant (Karl et al. 1998).

Whereas the strength of the relationship between DOCp and POCp does not provide straightforward information on which physiological mechanisms control DOC release (Marañón et al. 2004), a strong relationship would be expected if DOC release were merely a physiological process associated to actively growing cells (as opposed to other processes, including overflow mechanisms, grazing or lysis-mediated DOC release) (Teira et al. 2001a). The relatively weak relationship between DOCp and POCp rates found in our study (Fig. 6E,F) suggests that DOC release does not merely derive from excretion during phytoplankton active growth. Nevertheless, the relatively low mean PER values observed in surface waters off Vigo (ca. 10\%) indicate that actively growing phytoplankton cells could be the dominant process in these samples. Any process inhibiting cell growth and division but still permitting carbon assimilation may result in an overflow of photoassimilated carbon, which might uncouple POCp and DOCp rates and increase the relative DOCp (Mague et al. 1980, Wood \& Van Valen 1990). Such an enhanced relative DOCp has been repeatedly observed under very low light conditions (Thomas 1971, Berman \& Holm-Hansen 1974, Morán \& Estrada 2001, Marañón et al. 2004, 2005), and was attributed by some authors to the presence of senescent or light-limited cells. DOCp could be also enhanced at 

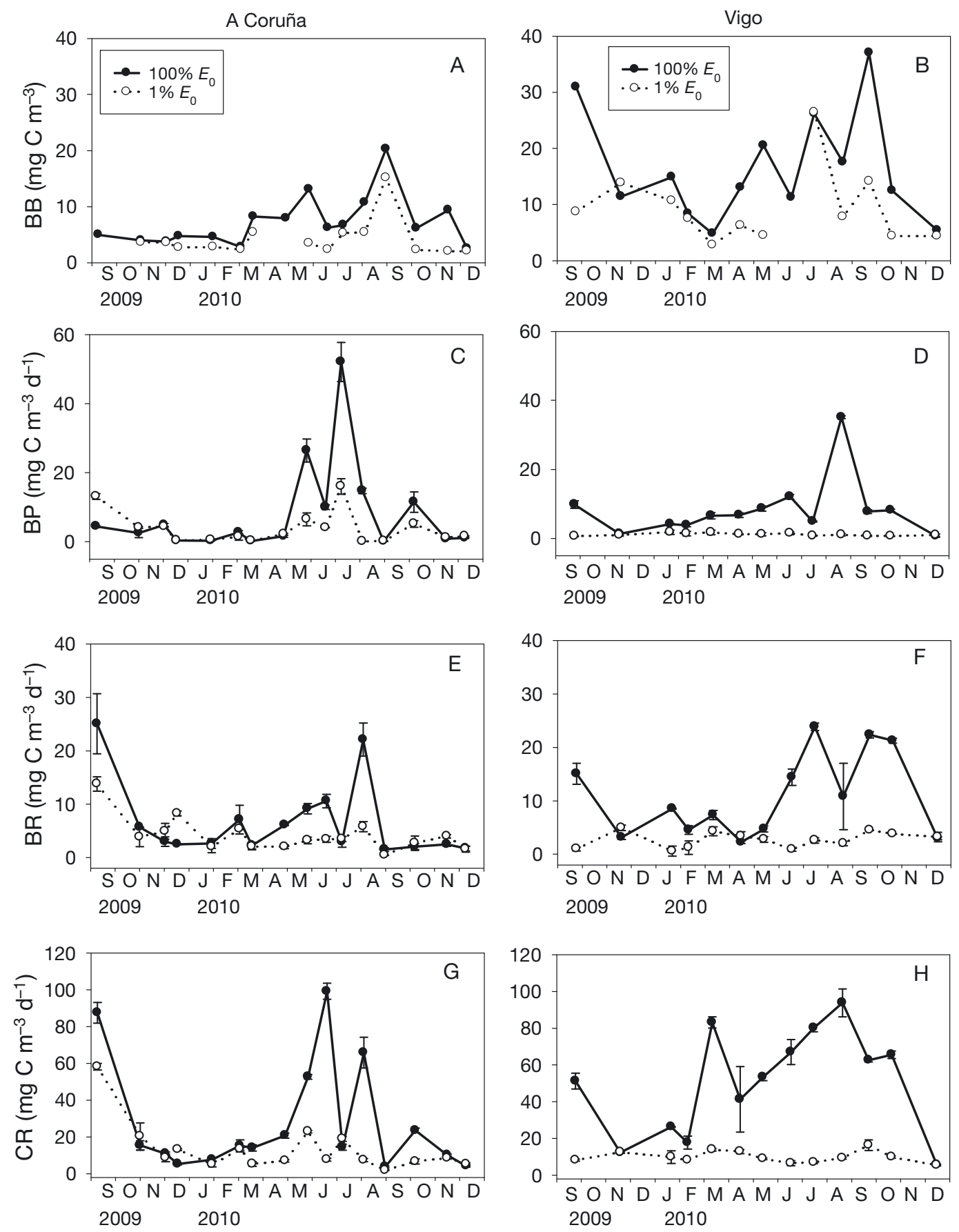

Sampling month

Fig. 7. Seasonal variation of mean $( \pm S E)(A, B)$ bacterial biomass $(B B),(C, D)$ bacterial production $(B P),(E, F)$ bacterial respiration $(\mathrm{BR})$ and $(\mathrm{G}, \mathrm{H})$ microbial plankton community respiration $(\mathrm{CR})$ at $100 \% E_{0}$ and $1 \% E_{0}$ (optical depths in percentage of surface photosynthetically available radiation) off $(A, C, E, G) A$ Coruña and $(B, D, F, H)$ Vigo

low light levels as a consequence of the inability of cells to proceed with macromolecular synthesis at the same rates as carbon fixation, which would lead to an accumulation of photosynthates that would be released to the external environment (Harding et al. 1985, Marañón \& González 1997). The high PER val- ues in surface waters off A Coruña do not seem compatible with excretion from actively growing phytoplankton cells (Sharp 1977). The relatively high PER values measured in surface waters off A Coruña during April and May 2010, when the nitracline depth was at 30 and $12 \mathrm{~m}$ depth (data not shown), respec- 

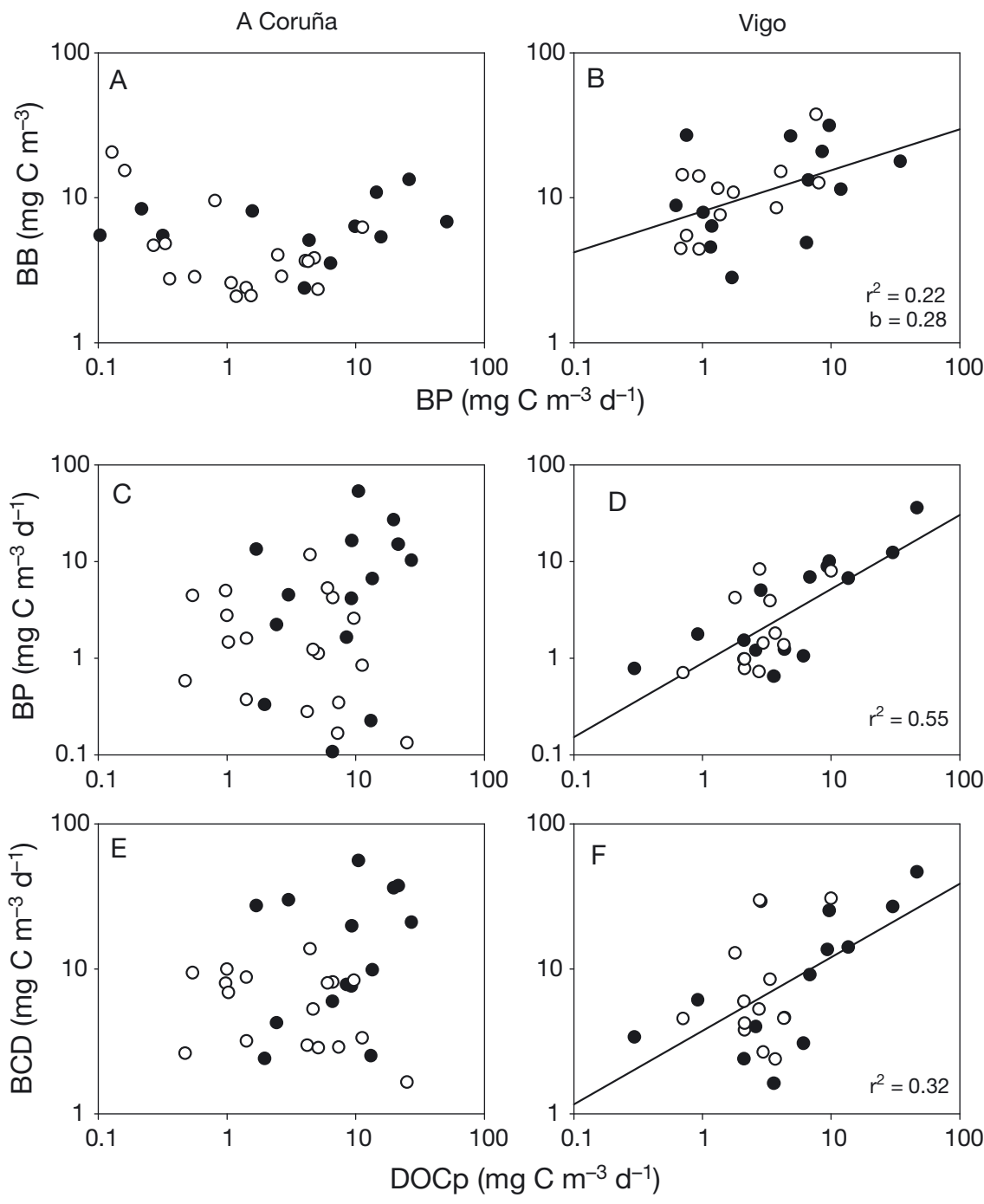

Fig. 8. Relationship between $(\mathrm{A}, \mathrm{B})$ bacterial biomass $(\mathrm{BB})$ and bacterial production (BP), (C,D) BP and dissolved organic carbon production (DOCp) and $(\mathrm{E}, \mathrm{F})$ bacterial carbon demand $(\mathrm{BCD})$ and DOCp off $(\mathrm{A}, \mathrm{C}, \mathrm{E}) \mathrm{A}$ Coruña and $(B, D, F)$ Vigo. Black and white symbols represent data from the upwelling and downwelling period, respectively

tively, could be related to an overflow mechanism as a consequence of the high irradiance levels and low nutrient availability. A high PER value was also observed associated with an excess of light and nutrient limitation by Conan et al. (2008). In this present study, we found a positive correlation between the nitracline depth and PER values in pooled surface samples during the upwelling period $\left(\mathrm{r}^{2}=0.60, \mathrm{p}<\right.$ $0.01, \mathrm{n}=14)$. The high PER values observed in surface waters off A Coruña during downwelling can be associated to the acclimation of cells to low irradiances and the subsequent photoinhibition during incubation. The shift from low irradiances within the upper mixed layer to high irradiances during incubation may promote the release of DOCp, possibly due to membrane damage (Myklestad 2000), as demonstrated in natural samples (Mague et al. 1980, Panzenböck 2007) or in cultures (Cherrier et al. 2014). Although differences in phytoplankton species composition between A Coruña and Vigo, which may influence both the amount and quality of DOCp (Wetz \& Wheeler 2007, Sarmento \& Gasol 2012, López-Sandoval et al. 2013), cannot be ruled out, it seems that differences in hydrographic conditions between these 2 nearby coastal stations determine the processes controlling phytoplanktonic DOC release.

\section{Phytoplankton and heterotrophic bacteria coupling}

Sources of DOC production in the sea include both direct phytoplankton release, which accounts for $\sim 20 \%$ of total production, and indirect processes such as cell lysis and grazing (Nagata 2000). Marine DOC concentration in surface waters generally varies within a narrow range (60-90 $\mathrm{HM} \mathrm{C)}$ (Benner 2002) compared to the larger variations in primary production, which suggests a tight coupling between production and removal processes. A strong linkage between phytoplankton and heterotrophic bacteria has been demonstrated for several areas, on the basis of a significantly positive correlation between primary and bacterial production rates (Lancelot \& Billen 1984, Cole et al. 1988, Morán et al. 2002), suggesting that DOCp by phytoplankton is a major source of organic carbon for bacterial growth. In contrast, other authors suggest an uncoupling between phytoplankton and bacteria, based on weak or non-significant relationships between organic matter release and bacterial production rates (Teira et al. 2003a,b) or based on estimates of bacterial carbon usage greatly exceeding concurrent estimations of DOCp (Williams \& Yentsch 1976, Bode et al. 2001, Rochelle-Newall et 
al. 2008, Fouilland \& Mostajir 2010), suggesting that bacteria do not exclusively rely on recently produced phytoplankton exudates. In the present study, the DOC supply by phytoplankton was insufficient to support BCD (Table 2), contributing on average $\sim 30 \%$ of BCD at both sampling sites, suggesting a moderate coupling between phytoplankton and bacteria, according to the criteria used by Fouilland \& Mostajir (2010). Similar or even lower values have been measured in oligo- to meso-trophic oceanic and coastal areas (Lignell 1990, Baines \& Pace 1991, Morán et al. 2002, Teira et al. 2003a,b, Alonso-Sáez et al. 2008, López-Sandoval et al. 2011), although in most of these studies BR was estimated rather than measured, which may have significantly affected the corresponding BCD estimates. By contrast, higher values can be found in highly productive systems (Fouilland \& Mostajir 2010, Morán et al. 2013). Unmeasured DOCp derived from indirect processes such as grazing or cell lysis could partially explain the observed low DOCp/BCD ratio. Lateral advection of allochthonous DOC could also sustain the high $\mathrm{BCD}$ rates, as previously observed in other coastal and estuarine areas (Morán et al. 2002, 2013). Although we do not have direct supporting data for this possibility during the sampling period, the significantly higher DOC concentration and FDOM-T values observed off A Coruña than off Vigo (Table 1) could be indicative of a higher influence of allochthonus DOM at that site. Several authors have observed that the $\mathrm{DOCp} / \mathrm{BCD}$ ratio is higher during high compared to low productivity periods (Teira et al. 2003a, Alonso-Sáez et al. 2008) and suggested a lag-phase between DOC release and bacterial consumption. The fact that the present study included more samples belonging to the unproductive (downwelling) than to the productive (upwelling) period would explain in part the mean low DOCp/BCD ratios measured at the sampling locations. Nevertheless, a recent study by Morán et al. (2013) specifically claims that even when bacterial carbon needs exceed concurrent DOCp, the trophic dependence of bacteria on freshly released photosynthates should not be overlooked.

Despite the similar DOCp/BCD ratio at both sampling sites, a significant relationship between $\mathrm{BP}$ and DOCp, with DOCp explaining $55 \%$ of the variance in BP, was observed off Vigo while such a relationship was not significant off A Coruña (Fig. 8C,D). A lack of correlation between both rates off A Coruña clearly indicates a short-term uncoupling between phytoplankton exudation and bacterial activity. As explained above, such a weak coupling may be expected when organic carbon sources other than freshly produced phytoplankton exudates are available for bacteria. Two additional non-excluding hypotheses for the uncoupling would be: (1) the quality of the freshly released DOC; and (2) the effect of other factors regulating bacterial dynamics.

The quality of the recently released DOC must have an important impact on the subsequent uptake by bacteria (Judd et al. 2006). Among the different substances released by phytoplankton are proteins, polysaccharides, nucleic acids, lipids and small molecules such as monosaccharides, amino acids or vitamins (Myklestad 2000). The quality of the released DOC varies with phytoplankton species composition (Sarmento \& Gasol 2012) and the growing phase (e.g. Myklestad 2000). Several studies concluded that lowmolecular weight compounds dominate the pool of organic carbon released from actively photosynthesizing cells (see review by Bertilsson \& Bones 2003), and that the low molecular weight fraction of released DOC is more rapidly used by bacteria than the high molecular weight fraction (Jensen 1983, Sundh 1992). If the cells become damaged due to stress factors, they may lose some or all of their soluble compounds (Myklestad 2000). Therefore, it is anticipated that the DOCp from actively growing phytoplankton would be more available to bacterial consumption than DOCp derived from overflow mechanisms, light-limitation, photoinhibition or indirect processes such as grazing or cell lysis. Indeed, a strong relationship exists between DOCp and BP rates off Vigo, where DOCp in surface waters seems to mainly result from actively growing phytoplankton. In contrast, other mechanisms such as overflow associated with nutrient shortage or rapid shifts in the ambient irradiance seem to control phytoplankton DOCp in surface samples off A Coruña-which may explain the lack of correlation between DOCp and BP. In this sense, Obernosterer \& Herndl (1995) demonstrated that nutrient-limited phytoplankton release a high amount of DOC which is not readily consumed by heterotrophic bacteria.

The connection between recently released phytoplankton exudates and bacterial production may be also modulated by the control exerted on bacteria by other regulating factors, such as inorganic nutrient availability, temperature or grazing pressure. The effect of temperature and inorganic nutrient availability on BP does not seem relevant in our area of study, as no significant correlations were found between $\mathrm{BP}$ and inorganic nutrient concentrations or temperature (data not shown). A recent study by Fouilland et al. (2014) demonstrated that a strong 
direct $\mathrm{C}$ coupling between bacteria and phytoplankton only occurs under early phytoplankton bloom conditions, when nutrient availability is very high and grazing pressure on microorganisms is very low. In contrast, an uncoupling between phytoplankton exudates and BP can be observed under strong grazing pressure. According to these authors, under such conditions, bacteria would essentially rely on DOC indirectly released as a consequence of predation on both phytoplankton and bacteria. Considering that the short-term ${ }^{14} \mathrm{C}$ incubations would barely detect this DOC pool, an uncoupling between DOCp and $\mathrm{BP}$ rates can be expected. We do not have direct estimates of grazing pressure on microbial plankton in our study. However, the exploration of the log-log relationship between $\mathrm{BB}$ and $\mathrm{BP}$ rates provide an estimation of the strength of the bottom-up (resource) control (Billen et al. 1990, Ducklow 1992). If predation mortality is low, all BP can be converted into BB, and thus, a strong relationship (with high slope) between BP and BB suggests domination of bottomup control of bacteria. Conversely, no relationship or low slope suggests domination of top-down control. The absence of a significant log-log relationship between both variables is indicative of an indiscernible bottom-up control off A Coruña, whereas a weak to moderate bottom-up control was observed off Vigo (Fig. 8A,B). The lower BB despite similar BP rates as well as the lower bacterial cell size off $A$ Coruña compared to Vigo (Table 2), further support the idea of a stronger top-down control in the former. Similarly, the lower percentage of variability of TOCp rates explained by chl a concentration off $A$ Coruña than off Vigo (Fig. 6A,B) suggest that grazing processes could also have more impact on phytoplankton off A Coruña. Therefore, it seems plausible that a strong top-down (grazing) control on microbial plankton community exists off A Coruña, which could additionally explain the short-term disconnection between DOCp and BP rates.

In summary, we have shown that differences in the mechanisms involved in DOC production may strongly influence the strength of the subsequent linkage between phytoplankton and heterotrophic bacteria at coastal sites showing very similar planktonic carbon budgets over the annual cycle. The degree of direct C-coupling between phytoplankton extracellular release and bacterial production appears to be modulated by the availability of the freshly produced exudates, which enhances direct carbon coupling, and the strong grazing pressure, which weakens the short-term coupling between phytoplankton release and bacterial production.
Acknowledgements. We thank all the people involved in the projects DIFUNCAR and RADIALES who helped sampling and the analytical work. We thank the crew of the R/V Lura and R/V J. M. Navaz for their help during the work at sea. POC analyses were made at the analytical facilities (SAI) of the Universidade da Coruña (Spain). G. Casas, A. F. Lamas M. P. Lorenzo and F. Rozada assisted with water sampling and filtration, F. Eiroa with flow cytometry analysis, M. J. Pazo with fluorescence and DOM analyses and V. Vieitez with nutrient analyses. This research was supported in part by the MEC project DIFUNCAR (CTM2008-03790/MAR) and by IEO project RADIALES. S.M-G. was funded by a FPU-MEC fellowship. V.H-M. was funded by a FPI-MEC fellowship. E.T. was funded by a Ramón y Cajal-MEC contract.

\section{LITERATURE CITED}

Alonso-Sáez L, Vázquez-Domínguez E, Cardelús C, Pinhassi J and others (2008) Factors controlling the yearround variability in carbon flux through bacteria in a coastal marine system. Ecosystems 11:397-409

Álvarez-Salgado XA, Figueiras FG, Fernández-Reiriz MJ, Labarta U, Peteiro L, Piedracoba S (2011) Control of lipophilic shellfish poisoning outbreaks by seasonal upwelling and continental runoff. Harmful Algae 10: 121-129

Baines SB, Pace ML (1991) The production of dissolved organic matter by phytoplankton and its importance to bacteria: patterns across marine and freshwater systems. Limnol Oceanogr 36:1078-1090

Benner R (2002) Chemical composition and reactivity. In: Hansell DA, Carlson CA (eds) Biogeochemistry of marine dissolved organic matter. Academic Press, San Diego, CA

Berman T, Holm-Hansen O (1974) Release of photoassimilated carbon as dissolved organic matter by marine phytoplankton. Mar Biol 28:305-310

Bertilsson S, Bones JB Jr (2003) Supply of dissolved organic matter to aquatic ecosystems: autochthonous sources. In: Findlay SEG, Sinsabaugh RL (eds) Aquatic ecosystems: interactivity of dissolved organic matter. Elsevier Science, San Diego, p 3-24

Billen G, Servais P, Becquevort S (1990) Dynamics of bacterioplankton in oligotrophic and euphotic aquatic environments: bottom-up or top-down control? Hydrobiologia 207:37-42

Bode A, Casas B, Varela M (1994) Size-fractionated primary productivity and biomass in the Galician shelf (NW Spain): netplankton versus nanoplankton dominance. Sci Mar 58:131-141

$>$ Bode A, Barquero S, Varela M, Braun JG, de Armas D (2001) Pelagic bacteria and phytoplankton in oceanic waters near the Canary Islands in summer. Mar Ecol Prog Ser 209:1-17

Butrón A, Iriarte A, Madariaga I (2009) Size-fractionated phytoplankton biomass, primary production and respiration in the Nervión-Ibaizabal estuary: a comparison with other nearshore coastal and estuarine ecosystems from the Bay of Biscay. Cont Shelf Res 29:1088-1102

Calvo-Díaz A, Morán XAG (2006) Seasonal dynamics of picoplankton in shelf waters of the southern Bay of Biscay. Aquat Microb Ecol 42:159-174

Cherrier J, Valentine S, Hamill B, Jeffrey WH, Marra JF 
(2014) Light-mediated release of dissolved organic matter by phytoplankton. J Mar Syst doi: 10.1016/ j.jmarsys.2014.02.008

Coble PG (1996) Characterization of marine and terrestrial DOM in seawater using excitation-emission matrix spectroscopy. Mar Chem 51:325-346

Cole JJ, Findlay S, Pace ML (1988) Bacterial production in fresh and saltwater ecosystems: a cross-system overview. Mar Ecol Prog Ser 43:1-10

> Conan P, Joux F, Torreton JP, Pujo-Pay M, Douki T, Rochelle-Newall E, Mari X (2008) Effect of solar ultraviolet radiation on bacterio- and phytoplankton activity in a large coral reef lagoon (SW New Caledonia). Aquat Microb Ecol 52:83-98

Ducklow HW (1992) Factors regulating bottom-up control of bacterial biomass in open ocean plankton communities. Arch Hydrobiol Beih Ergebn Limnol 37:207-217

Ducklow HW (2000) Bacterial production and biomass in the oceans. In: Kirchman DL (ed) Microbial ecology of the oceans. Wiley-Liss, New York, NY, p 85-120

Fouilland E, Mostajir B (2010) Revisited phytoplanktonic carbon dependency of heterotrophic bacteria in freshwaters, transitional, coastal and oceanic waters. FEMS Microbiol Ecol 73:419-429

Fouilland E, Tolosa I, Bonnet D, Bouvier C and others (2014) Bacterial carbon dependence on freshly produced phytoplankton exudates under different nutrient availability and grazing pressure conditions in coastal marine waters. FEMS Microbiol Ecol 87:757-769

González-Nuevo G, Gago J, Cabanas JM (2014) Upwelling index: a powerful tool for marine research in the NW Iberian upwelling system. J Oper Oceanogr 7:45-55

> Harding LW, Meeson BW, Fisher TR (1985) Patterns of photosynthetic carbon metabolism in light-limited phytoplankton. Mar Biol 89:121-133

> Judd KE, Crump BC, Kling GW (2006) Variation in dissolved organic matter controls bacterial production and community composition. Ecology 87:2068-2079

Karl DM, Hebel DV, Björkman K (1998) The role of dissolved organic matter release in the productivity of the oligotrophic North Pacific ocean. Limnol Oceanogr 43:1270-1286

Kirchman D, Knees E, Hodson R (1985) Leucine incorporation and its potential as a measure of protein synthesis by bacteria in natural aquatic systems. Appl Environ Microbiol 49:599-607

> Lancelot C, Billen G (1984) Activity of heterotrophic bacteria and its coupling to primary production during the spring phytoplankton bloom in the southern bight of the North Sea. Limnol Oceanogr 29:721-730

> Lignell R (1990) Excretion of organic carbon by phytoplankton: its relation to algal biomass, primary productivity and bacterial secondary productivity in the Baltic Sea. Mar Ecol Prog Ser 68:85-99

López-Sandoval DC, Fernández A, Marañón E (2011) Dissolved and particulate primary production along a longitudinal gradient in the Mediterranean Sea. Biogeosciences 8:815-825

López-Sandoval DC, Rodríguez-Ramos T, Cermeño $\mathrm{P}$, Marañón E (2013) Exudation of organic carbon by marine phytoplankton: dependence on taxon and cell size. Mar Ecol Prog Ser 477:53-60

Mague TH, Friberg E, Hughes DJ, Morris I (1980) Extracellular release of carbon by marine phytoplankton; a physiological approach. Limnol Oceanogr 25:262-279

Marañón E, González N (1997) Primary production, calcifi- cation and macromolecular synthesis in a bloom of the coccolithophore Emiliania huxleyi in the North Sea. Mar Ecol Prog Ser 157:61-77

Marañón E, Cermeño P, Fernández E, Rodríguez J, Zabala L (2004) Significance and mechanisms of photosynthetic production of dissolved organic carbon in a coastal eutrophic ecosystem. Limnol Oceanogr 49:1652-1666

Marañón E, Cermeño P, Pérez V (2005) Continuity in the photosynthetic production of dissolved organic carbon from eutrophic to oligotrophic waters. Mar Ecol Prog Ser 299:7-17

- Martínez-García S, Fernández E, Aranguren-Gassis M, Teira E (2009) In vivo electron transport system activity: a method to estimate respiration in marine microbial planktonic communities. Limnol Oceanogr Methods 7: 459-469

> Møller Jensen L (1983) Phytoplankton release of extracellular organic carbon, molecular weight composition, and bacterial assimilation. Mar Ecol Prog Ser 11:39-48

> Morán XAG, Estrada M (2001) Short-term variability of photosynthetic parameters and particulate and dissolved primary production in the Alboran Sea (SW Mediterranean). Mar Ecol Prog Ser 212:53-67

> Morán XAG, Estrada M, Gasol JM, Pedrós-Alió C (2002) Dissolved primary production and the strength of phytoplankton bacterioplankton coupling in contrasting marine regions. Microb Ecol 44:217-223

> Morán XAG, Ducklow HW, Erickson M (2013) Carbon fluxes through estuarine bacteria reflect coupling with phytoplankton. Mar Ecol Prog Ser 489:75-85

Myklestad SM (2000) Dissolved organic carbon from phytoplankton. In: Wangersky P (ed) The handbook of environmental chemistry, Vol. 5, part D, marine chemistry. Springer-Verlag, Berlin, p 111-148

Nagata T (2000) Production mechanisms of dissolved organic matter. In: Kirchman DL (ed) Microbial ecology of the oceans. Wiley-Liss, New York, NY, p 121-152

> Nieto-Cid M, Álvarez-Salgado XA, Pérez FF (2006) Microbial and photochemical reactivity of fluorescent dissolved organic matter in a coastal upwelling system. Limnol Oceanogr 51:1391-1400

Norland S (1993) The relationship between biomass and volume of bacteria. In: Kemp PF, Sherr BF, Sherr EB, Cole JJ (eds) Handboook of methods in aquatic microbial ecology. Lewis Publishers, Boca Raton, FL, p 303-307

Obernosterer I, Herndl GJ (1995) Phytoplankton extracellular release and bacterial growth: dependence on the inorganic N:P ratio. Mar Ecol Prog Ser 116:247-257

Panzenböck M (2007) Effect of solar radiation on photosynthetic extracellular carbon release and its microbial utilization in alpine and Arctic lakes. Aquat Microb Ecol 48:155-168

Parsons TR, Maita Y, Lalli CM (1984) A manual of chemical and biological methods for seawater analysis. Pergamon Press, Oxford

Robinson C (2008) Heterotrophic bacterial respiration. In: Kirchman DL (ed) Microbial ecology of the oceans, 2nd edn. Wiley-Liss, New York, NY, p 299-336

Rochelle-Newall EJ, Torréton JP, Mari X, Pringault O (2008) Phytoplankton-bacterioplankton coupling in a subtropical South Pacific coral reef lagoon. Aquat Microb Ecol 50: 221-229

Sarmento H, Gasol JM (2012) Use of phytoplankton-derived dissolved organic carbon by different types of bacterioplankton. Environ Microbiol 14:2348-2360 
Sharp JH (1977) Excretion of organic matter by marine phytoplankton: Do healthy cell do it? Limnol Oceanogr 22:381-399

Smith DC, Azam F (1992) A simple, economical method for measuring bacterial protein synthesis rates in seawater using 3H-leucine. Mar Microb Food Webs 6:107-114

Sundh I (1992) Biochemical composition of dissolved organic carbon derived from phytoplankton and used by heterotrophic bacteria. Appl Environ Microbiol 58:2938-2947

Teira E, Pazó MJ, Serret P, Fernández E (2001a) Dissolved organic carbon production by microbial populations in the Atlantic Ocean. Limnol Oceanogr 46:1370-1377

Teira E, Serret P, Fernández E (2001b) Phytoplankton sizestructure, particulate and dissolved organic carbon production and oxygen fluxes through microbial communities in the NW Iberian coastal transition zone. Mar Ecol Prog Ser 219:65-83

Teira E, Abalde J, Álvarez-Ossorio M, Bode A and others (2003a) Plankton carbon budget in a coastal wind-driven upwelling station off A Coruña (NW Iberian Peninsula). Mar Ecol Prog Ser 265:31-43

Teira E, Pazó MJ, Quevedo M, Fuentes V, Niell FX, Fernández E (2003b) Rates of dissolved organic carbon produc-

Editorial responsibility: Graham Savidge, Portaferry, UK tion and bacterial production in the eastern North Atlantic Subtropical Gyre during summer. Mar Ecol Prog Ser 249:53-67

Thomas JP (1971) Release of dissolved organic matter from natural populations of marine phytoplankton. Mar Biol 11:311-323

> Wetz MS, Wheeler PA (2007) Release of dissolved organic matter by coastal diatoms. Limnol Oceanogr 52:798-807

> Williams PJ le B, Yentsch CS (1976) An examination of photosynthetic production, excretion of photosynthetic products, and heterotrophic utilisation of dissolved organic compounds with reference to results from a coastal subtropical sea. Mar Biol 35:31-40

Williams PJ le B, del Giorgio PA (2005) Respiration in aquatic ecosystems: history and background. In: del Giorgio PA, Williams PJ le B (eds) Respiration in aquatic ecosystems. Oxford University Press, London, p 1-18

Wood AM, Van Valen LM (1990) Paradox lost? On the release of energy-rich compounds by phytoplankton. Mar Microb Food Webs 4:103-116

Zlotnik I, Dubinsky Z (1989) The effect of light and the temperature on DOC excretion by phytoplankton. Limnol Oceanogr 34:831-839

Submitted: October 21, 2014; Accepted: February 1, 2015

Proofs received from author(s): May 7, 2015 